\title{
Poesías completas de José María Heredia
}





\section{Poesías completas \\ de José María Heredia}

Edición crítica de

Tilmann Altenberg

Con la colaboración de Alejandro González Acosta

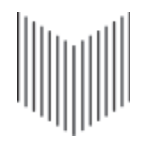

Iberoamericana-Vervuert

Madrid - Frankfurt

2020 



\section{Impreso con el apoyo de School of Modern Languages (Cardiff University).}

Cualquier forma de reproducción, distribución, comunicación pública o transformación de esta obra solo puede ser realizada con la autorización de sus titulares, salvo excepción prevista por la ley. Diríjase a CEDRO (Centro Español de Derechos Reprográficos) si necesita fotocopiar o escanear algún fragmento de esta obra (www.conlicencia.com;

917021970 / 932720447 ).

\section{Derechos reservados}

(C) Iberoamericana, 2020

Amor de Dios, 1 - E-28014 Madrid

Tel.: +34914293522 - Fax: +34914295397

(C) Vervuert, 2020

Elisabethenstr. 3-9 - D-60594 Frankfurt am Main

Tel.: +49695974617 - Fax: +49695978743

info@iberoamericanalibros.com

www.iberoamericana-vervuert.es

ISBN 978-84-9192-134-9 (Iberoamericana)

ISBN 978-3-96869-032-2 (Vervuert)

ISBN 978-3-96869-033-9 (e-book)

Depósito Legal: M-8433-2020

Imagen de la cubierta: Detalle de una litografía de Rocha y Fournier; dibujo realizado por [¿̨Pedro Cristóbal?] Verger, ¿1838?

Interiores de la cubierta: Manuscrito autógrafo de José María Heredia, 'A la Melancolía' (trad. de Ippolito Pindemonte) (José Augusto Escoto, Cuban history and literature collection, MS Span 52 (334). Houghton Library, Harvard University, Cambridge, MA)

Diseño de la cubierta: Rubén Salgueiros

Impreso en España.

Este libro está impreso íntegramente en papel ecológico sin cloro. 
